\section{Chekurin V., Ponomaryov Yu., Prytula M., Khymko 0.}

\title{
DEVELOPMENT OF AN APPROACH TO AUTOMATION OF GAS TRANSMISSION SYSTEM MANAGEMENT
}

Об’єктом дослідження є система управління газотранспортною системою (ГТС) України. Проведений аналіз показав, що ефективність ГТС стримується інформаційною гетерогенністю наявних засобів автоматизації та відсутністю автоматизованого обміну даними на вертикалі «керування технологічними процесами - стратегічне управління».

У ході дослідження застосували методологію, яку пропонує стандарт ANSI/ISA-95, еталонну модель функиіональної ієрархї управління виробничими підприємствами.

У результаті проведених досліджень визначені функції процесів, які діють на оперативному рівні. Розроблено підхід до поетапної автоматизачї управління ГТС. Він передбачає збереження та розвиток наявних засобів автоматизації технологічних процесів систем планування, оптимізації та керування магістральними газопроводами і підземними сховищами газу. За запропонованим підходом на основі існуючих комп'ютеризованих систем буде створена система автоматизаџї оперативного управління як МЕS система, яка задовольнятиме вимоги иього стандарту.

Впровадження запропонованого підходу можна розглядати як сукупність двох процесів, кожен із яких реалізується у три етапи, що виконуються ітераційно. Периий процес: створення системи оперативного управління як MES системи, запровадження автоматичного моніторингу параметрів фізичних і технологічних процесів та формування інформаційної системи у частині забезпечення оперативного управління та керування технологічними процесами. Другий процес: формування інформаційної системи в частині забезпечення бізнес-прочесів, впровадження автоматизованої системи корпоративного управління та впровадження автоматичного моніторингу бізнес-процесів.

Взаємодія цих двох процесів може виникнути лише у завершальній фазі остаточного формування інформаційної системи. Тому іх можна реалізувати паралельно, що забезпечить зменшення тривалості реконструкиї ГТС за запропонованим підходом. А це, у свою чергу, приведе до скорочення терміну окупності затрат на впровадження автоматизованої системи управління. Реалізачія запропонованого підходу в иілому дозволить підвищити керованість та ефективність роботи ГТС і створить умови для запровадження сучасних моделей управління.

Ключові слова: газотранспортні системи, автоматизація управління, стандарт ISA-95, MES cuстеми .

\section{Introduction}

The gas transmission system (GTS) is a complex of interconnected main gas pipelines (MP) and underground gas storage facilities (UGS) equipped with compressor stations, valves and other technological elements. The components of the GTS in the aggregate form a holistic engineering object. Effective and safe operation of this system is possible only with automation using mathematical modeling and computerization of all processes that determine its operation. The current state of automation of the management of the Ukrainian gas transmission system has been formed over the past decades as a result of the scattered modernization of individual gas transmission infrastructure facilities, individual technological processes and management areas. Automation of technological processes and computerization of GTS management at the operational and strategic levels were carried out without proper coordination of actions and the desire to ensure information compatibility of automation tools at various levels of management. One of the consequences of this is the lack of full automated data exchange on the vertical «process control - strategic ma- nagement». Therefore, it is relevant to develop an approach to automating the management of GTS at the operational and strategic levels with the provision of automated information exchange throughout the vertical «process control strategic management».

\section{The object of research and its technological audit}

The object of research is the management system of Ukrainian GTS, which covers five areas of management: information processes, business processes, gas transmission, underground gas storage and operation of engineering infrastructure.

GTS is a logistic system, which includes the engineering and production complex (IPC), organizational structure, production personnel, material and financial resources. Business processes that take place in this system create additional value and are crucial for its functioning as an economic system. The result of business processes are order flows, execution of which takes place with the IPC use, production and technological processes. 
GTS IPC is an object of the material world, which let's considered as an open thermodynamic system consisting of two main subsystems - GTS structures and gas accumulated in them. Constructions are GTS components, gas-filled main pipelines (MP), compressor stations (CS), stratums of underground gas storage facilities (UGS) and other technological elements. The interaction of the two subsystems between themselves and with the environment occurs through the exchange by mass, momentum and energy. Through the inputs and outputs of the GTS gas subsystem is exchanged with the external environment mass, momentum and energy.

The implementation of technological processes is accompanied by physical processes that occur in GTS gas, in the GTS structures and the environment. Thus, GTS as a physical object is a controlled nonlinear dynamic system with distributed parameters, characterized by significant dimensions and inertia, the effect of distributed and concentrated control actions, significant uncertainty of the values of internal parameters and external factors.

The processes of mass, momentum and energy transfer by gas mixtures, the energy and thermal interaction of the GTS gas with the GTS structures are constitutive for GTS functioning as a physical system. As well as the exchange of mass, momentum and energy with the environment, the processes of deformation, aging and destruction of structures.

Information processes are responsible for the gathering and accumulation of data about:

- parameters of physical processes occurring in GTS gas;

- GTS structures and the environment;

- parameters of technological processes;

- state of the processing equipment;

- material and financial resources and economic efficiency of the GTS;

- actual state and development trends of production and intellectual potentials.

An important function of information processes is maintaining information flows between the GTS subsystems of the various levels of management and adjacent gas transmission systems.

Let's consider the state of GTS automation management in different directions.

According to the Department of Automation and Communications of JSC «Ukrtransgaz», a corporate computer network, which has 100 nodes throughout Ukraine, is used in the Company. With the use of Hyper-V and Oracle-VM platforms, a virtual computing environment is implemented in the network. The company has a domain controller, a directory and DNS services, which provide the unified authentication and authorization of the users and delimitation of their access rights to directories and resources, and a united data warehouse. The Microsoft System Configuration Manager and System Operation Manager services provide monitoring of the state of the entire IT infrastructure, automatic software updates, remote management of all workstations, and anti-virus protection. JSC «Ukrtransgaz» has introduced corporate communication services - the unified communications system MS Lync 2013 and the unified corporate email system based on MS EXCHANGE 2013, as well as the IP telephony system.

A united database of operational dispatching information (UDOPI), which operates under the management of the ORACLE Database Management System, has been created.
This database receives data from automation systems of gas distribution and gas measuring stations, as well as from SCADA systems of CS and UGS.

Information processes automation system also includes a centralized IT service, which supports:

- a single window for recording IT incidents;

- distribution of requests among IT experts in accordance with their areas of responsibility;

- accounting for the implementation of requests for maintenance;

- round-the-clock user consultations.

The corporate-level management automation system includes the accounting and analytical system, which processes UDOPI data, the videoconferencing and party-line communication systems as well as the electronic document management system Megapolis.DocNet. In the Company also operates a comprehensive automated management system created on the basis of SAP ERP software [1], with the use of which financial accounting policy is implemented.

At the operational level special-purpose software systems are used. They were created by LLC Mathematical Center (Lviv, Ukraine) and the department for developing systems for the optimal planning and forecasting of the operating modes of GTS of the Ukrtransgaz Gas Transportation Research Institute (Kharkiv, Ukraine) [2, 3].

At the process control level, automation systems for the pipeline linear part, CS and UGS are installed. For the linear part, the systems of telemechanics, automation of electrochemical protection, and automation of gas distribution stations are used. To control the parameters of gas flows in the MP, flowline-collector systems and in the wells of UGS use instruments for measuring the technological parameters of gas - pressure and temperature are used. Recently, superimposed ultrasound systems have been installed to measure the flow velocity in pipelines. The automation system for technological objects consists of disparate control systems for compressor stations of the linear part and UGS created of components of ClearSCADA Schneider Electric (France), Serx Controls Ltd (Australia) SCX, Wonderware (USA), InTouch, etc. However, the full automation of technological processes in JSC «Ukrtransgaz» is missing. The available means of automation of technological processes are heterogeneous in their system and technical solutions and often informationally incompatible.

In general, it should be stated that the effectiveness of the GTS management system is significantly restrained by the information heterogeneity of the available automation tools and the lack of automated data exchange on the vertical «process control - strategic management».

\section{The aim and objectives of research}

The aim of research is development of a concept of a phased modernization of Ukrainian GTS basing on the methodology provided by the ANSI/ISA-95 standard [4, 5], through creating a computerized Manufacturing Operations Management (MOM) system as Manufacturing Execution Systems (MES) [6, 7].

To achieve this aim it is necessary to perform the following objectives:

1. To analyze the existing approaches to automating the management of GTS.

2. To develop a logistic model of GTS. 
3. To adapt the MES paradigm as a conceptual basis for creating the GTS MOM automation system of the developed logistics model.

4. To determine, according to the MES paradigm, the information exchanged by the GTS MOM system with its neighboring systems.

5. To determine, according to the MES paradigm, the functions and content of the processes that operate at the MOM level in accordance with the activity model defined by the standard ANSI/ISA-95.

\section{Research of existing solutions of the system}

There are a lot of offers on the market of software and hardware systems for automation of manufactoring enterprises management. Some of them are built according to the ANSI/ISA-95 standard.

To automate technological processes, they use intelligent systems designed to process data coming from sensors, as well as to generate control signals for actuators. These are PLC programmable logic controllers, distributed automatic control systems, SCADA systems [8] and batch systems [9].

Emerson Process Management (USA) is a supplier of SCADA solutions for gas transmission and distribution systems, as well as software, remote terminals and computer gas flow meters [10]. OSI Soft (USA) is a developer and supplier of the PI System - software system for managing real-time data and events [11].

At the operational management level, automation systems are used to support four areas - production management, maintenance, quality and inventory. In addition to MES, these include:

- Laboratory information management systems LIMS [12];

- Warehouse Management Systems WMS [13];

- Computerized Maintenance Management Systems

(CMMS) [14].

The PSI GMS complex from PSI (Germany) [15] can be attributed to systems of this level. This is a modular application system for automated control, monitoring, analysis and management in the gas transmission industry. The SIMONE system developed by the Simone Research Group (Czech Republic) [16] are designed to simulate the processes in gas transmission networks, manage and dispatch these networks.

It should be noted that in the above-mentioned operational automation systems excessively simplified models of technological processes are often used. They do not take into account some specific features of the Ukrainian GTS, therefore their implementation requires substantial adaptation of the software, revision, and changing of technological process automation systems. All these require significant costs that are economically unreasonable for current time.

To automate management at the strategic level are used:

- PLM (Product Lifecycle Management) systems [17];

- ERP (Enterprise Resource Planning) systems [2];

- CRM (Customer Relationship Management) systems [18];

- HRM (Human Resource Management) systems.

SAP AG Corporation (Germany) [19] develops ESA solutions (Enterprise Software Application) - enterprise software for managing business processes and customer interaction.

The ANSI/ISA-95 standard forms a conceptual framework within which, using modern computer and information and communication technologies, it is possible to solve the problem of automating the management of GTS in an integrated manner. According to this approach, known as TIA (Totally Integrated Automation) [20], automation systems at various management levels, from PAS to ERP, should be created from scratch. Thanks to this, it would be possible to naturally achieve continuity of information flows in both directions of this vertical, as well as on the horizontals of each level management.

However, the use of TIA approach for the automation of Ukrainian GTS, which would be a thoroughgoing solution to the problem, requires not only a radical modernization of the entire gas transmission infrastructure, but also the introduction of completely another management technologies. The implementation of such a task at the present stage requires too large investments both in infrastructure development and in human resources. Therefore, it is advisable to modernize the GTS management in an evolutionary way by transforming the existing means of MOM automation into MES system [21, 22].

\section{Methods of research}

Let's take standard ANSI/ISA-95 $[4,5]$ as the conceptual basis for the automation of the management of Ukrainian GTS (the corresponding international standard is known as IEC 61512). According to this standard, one should begin with automation of the operational level and vertical information flows. The standard proposes to solve this problem using MES as an MOM automation system $[6,7]$. The standard is based on the Purdue Enterprise Reference Architecture (PERA) model of the corporation's functional hierarchy [23].

According to this model, management of logistics systems is considered as a five-level structure. At the zero level, physical processes take place. The first level of the model is responsible for the direct control by physical processes and primary measurement of their parameters. Here actuators and primary transducers of physical quantities (sensors) act. The second level is responsible for monitoring of parameters of physical processes of zero level, parameters of operating modes and the state of the processing equipment, product characteristics, environment, and the like. For this, signals from the first sensory level are used. The hardware and software of the second level generates control signals for the technological equipment in accordance with commands from the third level.

The third level of the functional hierarchy represents MOM. It is intermediate between the second level and the level of business planning and logistics. Here algorithms for managing by production personnel and for controlling by technological equipment, parameters of technological processes, material resources, energy and product are formed.

The fourth level (business logistics and planning) covers the management of business processes that determine the production activities of the entire enterprise. Its goal is long-term and short-term production planning, supply and sales, management of modernization and development of production, and the like.

One of the main MES functions is transmission of information from the technological level to the administrative one and transfer information in the opposite direction from the corporate level to the operational level and transmits it from there to the distributed system of GTS enterprises, 
divisions, and technological facilities [8, 9]. MES implements these functions, providing interaction of application software systems of business logistics and planning, such as Enterprise Resource Planning (ERP), with process automation systems, such as SCADA or batch solutions.

The standard also defines models and functions of MOM level, which MES implements. Models define the boundaries of MES between PAS (below) and ERP (above) and define the data by which these applications exchange among themselves, realizing these functions.

\section{Research results}

6.1. Logistics of gas transmission and storage. GTS is a specific logistic system. It creates additional value by implementing two main types of processes - gas transmission and gas storage.

Each such process is performed on the order of a client, has a clearly defined time frame - the beginning and the end (Fig. 1) and, in addition, is characterized by a certain unique set of other constitutive parameters. Therefore, the GTS at the level of strategic management can be viewed as a discrete production, which outputs are fulfilled orders for transportation or storing of certain masses (volumes) of natural gas. The consumer of such a product is the client of the corresponding services.

An important feature of the GTS operation is that the sets of orders of each type form continuous flows of orders, so that at any moment of time a certain number of orders for transmission and/or storing are fulfilled. As shown for example in Fig. 1, at the time $t$, two processes of the «transmission» type and three «storage» types are performed. The flow of orders on tranmission forms a continuous gas flow in the MP. The flow of external orders on gas storage can interrupt, but to preserve the functionality, each UGS at any time must contain a certain amount of gas (so-called buffer gas). The storing of the buffer gas can be considered as an internal order of the GTS, which is carried out throughout the entire life cycle of the UGS.

Thus, at the zero, first and second levels of the PERA model, continuous physical, technological and information processes take place. At the third level, discrete processes (order management and control of their implementation) are transformed into continuous processes (management of technological personnel, control by physical, technological and information processes and monitoring of their parameters). At the fourth level, as already noted, discrete processes (planning orders and monitoring their implementation) act.
«Gas transmission» is a product of the GTS, which is characterized by the constitutive parameters:

- moments of start and finish, and duration;

- segments of MP and UGS networks that are involved in the fulfillment of the order;

- list of GTS inputs for gas recovery;

- gas recovery schedules for each input;

- gas quality indicators at the inputs, such as pressure, density, temperature, component composition, humidity, etc.);

- list of GTS outputs for gas supply;

- gas supply schedules for each output;

- gas quality indicators at the outputs.

The considered parameters form the set of external constitutive parameters for the product «gas transmission». In addition to them, there are also internal parameters, which are important for the «product», since they affect its cost, but do not matter to the consumer. For this type of product, one can distinguish three internal parameters:

- distribution of gas flows in the MP of the network segment;

- UGS resources that have to be used to fulfill the order;

- power schedules for the compressor stations of this segment, necessary for fulfilling of the order.

«Gas storing» is a product of GTS, which is characterized by the moments of its start and finish. To realize this product, it is necessary to deliver a defined amount of natural gas from defined GTS recovery inputs to defined UGS, pump it into the porous stratums, then store it for certain periods. At last one should withdraw the gas from the stratums and deliver it to defined supply GTS outputs.

The external constitutive parameters of this product are the totality of the sets of defining parameters for the two transport processes, as well as the segments of the MP and UGS networks involved in the fulfillment of this order.

The first transport process has constitutive parameters:

- set of recovery GTS inputs;

- gas recovery schedule for the inputs;

- gas quality indicators for the inputs;

- list of UGSs for gas storing.

And second:

- list of UGSs for gas storing;

- gas withdraw schedules from UGS;

- list of supply GTS outputs;

- gas supply schedules for each output;

- quality indicators for each output.

For the product «Gas Storing» one can distinguish between external and internal constitutive parameters. In particular, the processes that occur directly at the UGS, would be attributed to the internal, since the consumer does not care in which storage facilities and how its gas is stored. Whereas it can be very important for the company, because can substantially affect the product cost.

6.2. Activity model at the level of GTS operational management. Management at the MOM level within each zone one can implement using well-defined processes (activities). The c-MES model (Collaborative MES), introduced by the international association MESA in 2004, considers 8 basic management processes at the operational level and defines their main tasks 
and the interaction between them, as well as the lower and upper levels of management [24].

Fig. 2 shows a diagram of the interaction of the GTS operational management processes in accordance with the ANSI/ISA-95 standard. It also shows the information flows, by which the MES exchanges with the lower (second) and upper (fourth) levels of management.

As follows from Fig. 2, the MOM level receives order plans for the next period from the fourth level. They are the input data GTS operational management and tasks execution. From the third level into the second one the data about MP, CS and UGS configuration, their modes of operation, as well as instructions for the personnel and control signals for equipment arrive. From the second level the MOM level receives acknowledgements and data of physical and technological processes monitoring.

Let's consider the functions and main tasks of the processes of the third level.

Detailed order planning is aimed at creating detailed schedules for personnel management, control by configuration of $\mathrm{MP}$ and UGS equipment and modes of their operations. Its main tasks are:

- to determine duties, schedules of the operating staff in the area of responsibility of the MOM level;

- to develop models of personnel behavior in emergency cases;

- to create schedules for controlling by the cranes and other regulating and measuring equipment MPs; - to create schedules for controlling by the cranes and other regulating and measuring equipment of CSs; - to create schedules for controlling the operation modes of compressors at all CSs;

- to create schedules for controlling by the configuration of the working well complex at the UGS facilities controlling by the cranes, regulating and measuring equipment of flowline-collector systems;

- to create schedules for controlling by UGS CSs operating modes;

- to calculate the free capacities of GTS for each period; - identify bottlenecks for each order and each period of work.
Dispatching involves managing the technological routes of execution of orders by forming of executive instructions for personnel in the form of outfits, tasks, orders as well as generation of control signals for technological equipment. Its main tasks:

- to form executive instructions for operating personnel in the areas of responsibility of the third and second levels, as well as generate control signals for the relevant equipment:

1) MP configuration;

2) MP CS configurations;

3) modes of operation of the compressors at the compressor station;

4) configuration of a complex of working wells in the UGS;

5) modes of UGS CS operation;

- to monitor the performing by the personnel and equipment of executive instructions and control signals; - to track the correspondence of the actual consumption by technological objects of fuel gas, electricity and consumable with the corresponding normative indicators; - to form instructions for personnel management and control signals for equipment and transfer them to execution in situations which are not provided by detailed production schedule;

- to work out unpredictable situations threatening to orders fulfillment.

Executive management is the process for managing by physical and technological processes of gas transportation and storing. Main tasks:

- to transmit on the second level in real-time the instructions and signals for managing by configuration of MPs and to monitor of their execution;

- to transmit on the second level in real-time the instructions and signals for managing by configuration of CSs and to monitor of their execution;

- to transmit on the second level in real-time the instructions and signals for managing by operational modes of CSs and to monitor of their execution;

- transmit to the second level in real time commands and control signals of cranes by the regulating and measuring equipment of the UGS flowline-collector systems and monitor their passage; - to transmit on the second level in real-time the instructions and signals for managing by operational modes of UGS CSs and to monitor of their execution; - to receive of the monitoring data from the second level;

- to provide the data obtained from the second level to other processes of the third and fourth levels in accordance with established regulations or at their requests.

Resource management is a process that is responsible for collecting, accumulating, analyzing and exchanging information about resources and creation of algorithms and instructions to manage them in real time. The main tasks:

- to determine the levels of professional training, work experience, manager's and other qualities of employees, which are necessary to perform various duties in the area of responsibility of the third level;

Fig. 2. Model of activity at the operational management level 
- to determine the operational properties of equipment, measuring instruments and computer hardware, which can be used in processes operating in the area of responsibility of the third level;

- to establish requirements for software tools, which can be used in processes operating in the MOM;

- to establish requirements for communication facilities, which can be used in processes operating in areas of MOM responsibility;

- to determine the regulatory indicators of consumption of fuel gas, electricity, lubricants and other consumables for process facilities;

- to provide information on the availability of resources of various types at the request of other processes and/or personnel;

- initiate requests from personnel or other processes, which operate in the areas of responsibility of the third and fourth levels, obtaining resources for creation of new production processes;

- confirm the availability of resources for performing certain tasks to verify and their availability.

Product definition is information for management by the constitutive parameters of the orders. Main tasks:

- to define the external constitutive parameters;

- to define the internal constitutive parameters, such as:

1) network segment, involved in the implementation of the order;

2) flow distribution in this network segment;

3) schedules of CS power in the segment;

4) UGSs for gas storing according to the order;

5) UGSs for gas withdrawal according to the order;

6) the time moments of the start of filling and withdrawal

of the gas for each of the involved wells of the UGS;

- maintain the interface between the processes of the

MOM and ERP levels;

- transfer of data and to level II.

Data collection is a process responsible for the collection, accumulation, and distribution of the monitoring data about parameters of physical and technological processes, equipment status, and material resources. Main tasks:

- to collect the monitoring data of physical and technological processes;

- to collect the data on resource consumption (labor, fuel gas, electric power, consumables);

- to collect the monitoring data on the state of the process equipment and the UGS reservoirs;

- to collect the monitoring data on the state of the monitoring equipment, computing equipment, software, and communication channels operating at levels I-III;

- to collect the of data monitoring the integrity of the process equipment;

- to track of abnormal and emergency situations;

- to collect the data on the functioning of the personnel operating at levels I-III;

- to support of interfaces with the processes «executive management», «performance analysis» and «production tracking».

Performance analysis is the process responsible for analysis and reporting on the performance of the MP and UGS, as well as the effectiveness of the implementation of the orders. The main tasks:

- to calculate continuously of the specific costs consumed by MP and UGS resources (overhead costs, labor costs, depreciation, fuel gas, electricity, consumables etc.);
- to calculate of the resource costs consumed for each order execution;

- to calculate for each order the optimal constitutive parameters satisfying the criteria of minimum of resources cost;

- to compare the real order costs with the optimal one; - to calculate for each planning period the optimal constitutive parameters satisfying the criteria of minimum of resources cost;

- to compare the real specific costs for the planning period with the optimal ones;

- to compare resource costs for different orders;

- to compare specific costs for different planning periods;

- to calculate performance indicators for MP, CS. UGS, network segments and the entire GTS;

- to maintain the interface between the processes «data selection» and «production tracking».

Production tracking is reporting on technological processes and the implementation of the orders. The main tasks:

- to calculate continuously the mass balance of gas for each order, for control segments of GTS (for example, for the regional branches) and for the entire GTS network;

- to detect continuously leakages in the MP and CS and identification of their parameters (location, intensity); - to compare continuously the data on the recovery and supply of gas for each order with customers' data; - to receive data from other processes acting on MOM level (Fig. 2);

- to transfer data to the process «detailed planning» and the fourth level of management;

- to document in real time the events related to the execution of orders: the beginning and end, the violation of the schedules of recovery and supply, the violation of the quality indicators in the inputs and outputs etc.;

- to generate information necessary for documenting (tracking) and analyzing (tracing) the processes of order fulfillment;

- to generate and provision of information on technological processes in the MP and UGS and about orders fulfillment in accordance with a defined schedule and/or upon requests from personnel and processes operating in the areas of responsibility of the third and fourth levels.

6.3. The concept of the phased automation of the Ukrainian GTS management. Let's consider the approach to automating the GTS of Ukraine, which provides gradual increase in the functionality of the automated management system (Fig. 3). It provides, first of all, the creation and implementation of a management automation system at the MOM level as MES system according to the ANSI/ISA-95 standard.

Operational management systems are the most specific. Its functionality is rigidly connected with technological processes and is based on mathematical models of production equipment, constitutive parameters of physical processes, the environment and the like. Therefore, it is almost impossible to take one of the existing MES systems and configure it for use in the Ukrainian GTS. As it turned out, it is also not possible to adapt the MES systems, which were created for other gas transmission systems and are successfully used, since the Ukrainian gas transmission 
system has specific characteristics that were not taken into account when these systems were built.

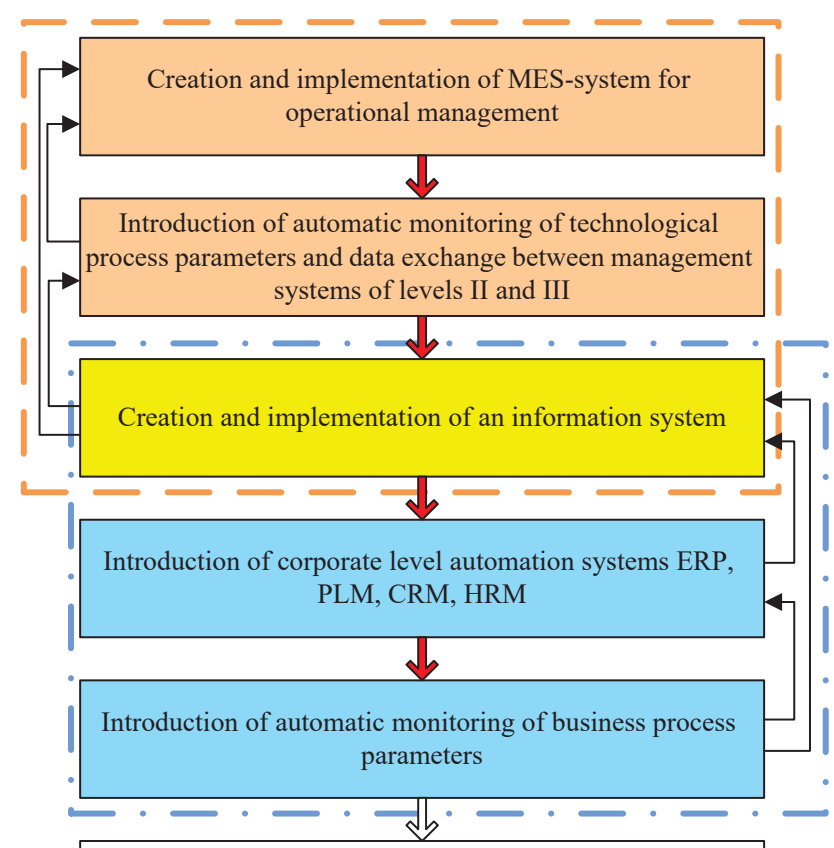

Implementation of the process management model

Fig. 3. Algorithm of the phased automation of management by Ukrainian gas transmission system

At the same time, JSC «Ukrtransgaz» has already implemented and successfully utilize systems that implement a number of functions specific to MES. These are software systems MPOC MP and MPOC UGS. The development team maintains the software complexes and continuously extends their functionality in accordance with the needs of the users of these systems. Therefore, it is advisable to build the MES system for the Ukrainian gas transmission system on the basis of these complexes by the specialists who created them, carry out their maintenance and thoroughly know the specifics of the Ukrainian gas transmission system.

The second stage (Fig. 3) is the introduction of automatic monitoring of the parameters of technological and physical processes and their transfer to the level of operational management. After this stage, executive instructions for personnel and control signals for equipment, which are formed at the third level, are automatically transmitted to the second (technological) level, and the signals and acknowledgment messages from the second level are automatically passed to the third one.

The next stage is the creation and implementation of an information system (IS), the structure and operation of which is consistent with the MES methodology, the PERA model and the process management model. At this stage, automatic data exchange between the system of MOM level and specialized IS databases will be introduced.

The system of operational level will allocate in thematic databases, after preliminary processing:

- data of monitoring of physical and technological processes parameters;

- data about executive instructions and control signals transmitted at the technological level;
- data about messages and signals received by MES from the second level in response.

The next step is the implementation of automation systems of corporate level, such as EPR, PLM, CRM, HRM, and the like. The business logic of these systems generations the information for the fourth level users on the base of the data stored in IS, present it in appropriate formats according to requests of the users.

It should be noted that the functionality of corporate level systems is not as closely related to technological processes as those of MOM and PAS levels. Therefore, it is possible to use existing enterprise-level software systems (for example, from SAP AG or others), which allow to customize their functionality to the specific needs of users.

At the fifth stage, automatic monitoring of the parameters of all business processes is implemented. The business logic of computerized management systems operating at the second, third and fourth levels provides automatic storing of data on the made by them transactions in the corresponding IC database. At this stage information exchange between the fourth and third levels is introduced according to the MES methodology through the corresponding thematic IS databases.

\section{SWOT analysis of research results}

Strengths. Automating the GTS management on the proposed approach is a combination of two processes - the creation of an automated operational management system and the creation of an automated corporate management system. Each of these processes consists of three tasks that are performed iteratively. The first process (in Fig. 3 circled in a dashed line) involves steps one through three, and the second process (circled in Fig. 3 with a dashdotted line) from the third to the fifth. At the initial stages of implementation, these two processes practically do not interact. The interaction is possible only at the stage of the final IS formation. Therefore, they can be implemented in parallel. As a result, the time taken to implement the automation system is reduced, and, consequently, the payback period for the GTS modernization is reduced.

MOM-level systems are the most specific of all GTS management automation systems. Their functionality is rigidly connected with technological processes and is based on mathematical models of technological equipment, defining physical processes, environment of GTS operation, and the like. Therefore, according to the proposed approach, an automation management system should be created as an MES system based on the existing software packages MPOC MP and MPOC UGS, which are already used in the operational management, by the developers of these complexes. This will make it possible to take into account the specific characteristics of the GTS of Ukraine, and therefore significantly reduce the cost of designing MES, its implementation, staff training, maintenance, and the like.

Weaknesses. According to the proposed approach, in order to reduce costs, the automation of the management of GTS will be carried with the maximum possible preservation of existing software and hardware means of computerization, which are now in operation at JSC «Ukrtransgaz». This can adversely affect the functionality of the MES, as the system operational level. This is especially true of 
the existing IT infrastructure in the company. Under such conditions it will undoubtedly affect the architecture of the created automation system, what, of course, will limit the freedom of its developers. This, in turn, can affect the effectiveness of the MES system that will be created.

Opportunities. The functionality of management automation systems at the corporate level is not as closely related to technological processes as at the MOM level. Therefore, it is possible to use software systems available on the market, for example, from corporation SAP AG or others, customizing their functionality for the needs of the GTS.

The implementation of the proposed approach will create conditions for the implementation of the process management model [25] in the gas transmission system. This, in turn, will significantly reduce transaction costs, increase staff motivation, introduce a customer-oriented approach in GTS management.

Threats. Implementation of an automated management system will lead to a reduction in the number of personnel involved in GTS management at different levels. In addition, the managers will be required to master modern technology using computerized systems without intermediaries. The use of key performance indicators (KPI), calculated automatically on the basis of monitoring data parameters of business processes, eliminates the role of the subjective assessment of the activities of management personnel. All this will create psychological stress in the collectives and may cause the opposition of the GTS management to the introduction of the automation system.

\section{Conclusions}

1. The conducted analysis shows that on the market of software and hardware automation systems for managing by industrial enterprises are sufficient proposals intended for the gas transmission industry. Some of them are consistent with the ANSI/ISA-95 standard. However, MOM-level systems are the most specific of all GTS management automation systems. Their functionality is rigidly connected with technological processes, depends on the characteristics of the equipment, the environment of the GTS operation and the like. In addition, the cost of ready-made solutions and their adaptation to the realities of the Ukrainian GTS is too high. The key point of the proposed approach is the creation of an automation system for operational management as an MES system in accordance with the ANSI/ISA-95 standard methodology. It is proposed to create it on the basis of the existing software systems MPOC MP and MPOC UGS, which are already used in the operational management by the developers of these complexes.

2. The logistic model of the GTS has been developed. It has an important specific feature in comparison with traditional production systems of discrete, batch or continuous type. Its peculiarity is that at the corporate and partially at the operational management levels there are discrete business processes of processing of orders for transmission and storage of certain volumes of natural gas. At the operational level, these discrete processes are provided by appropriate management by continuous technological and physical processes in the MP and UGS.

3. To accomplish this transformation, the MES paradigm in the proposed approach is adapted to the GTS logistics model by appropriately defining the information flows that the MES exchanges with neighboring levels. As well as by defining of the functions and contents of processes, that operates at the MOM level, in correspondence of the model of activity of systems of this level.

4. In accordance with the accepted MES logistics model, the system exchanges with the corporate-level systems by the information about external order parameters, transmits data on free capacity of the MP and UGS to it, and receives plans for the implementation of gas transmission and storage orders from the top level. MES transmits to the technological level the data about configurations of MP, CS and UGS, and the executive instructions for personnel and control signals for equipment, which are necessary to manage the continuous technological and physical processes to ensure the fulfillment of the planned orders. From the second level, MES receives acknowledgment messages and the data of physical and technological processes monitoring.

5. The functions and contents of processes operating at the level of operational management are defined such, to ensure the transformation of parameters of discrete processes, that come from the corporate level, into executive instructions for the personnel management and control signal for technological equipment. This is necessary to ensure the proper management by continuous technological and physical processes.

\section{References}

1. Magal S. R. Word Jeffrey Integrated Business Processes with ERP Systems: monograph. Wiley Publishing, 2011. 358 p.

2. Prytula N. M., Gryniv O. D., Dmytruk V. A. Simulation of nonstationary regimes of gas transmission systems operation // Mathematical modeling and computing. 2014. Vol. 1, Issue 2. P. 224-233

3. Prytula N., Prytula M., Boyko R. Development of software for analysis and optimization of operating modes of underground gas stores // Technology Audit and Production Reserves. 2017. Vol. 2, Issue 3 (40). P. 17-25. doi: http://doi.org/ $10.15587 / 2312-8372.2018 .128574$

4. ISA 95.00.03-2013. Enterprise-Control System Integration, Part 3: Models of Manufacturing Operations Management (IEC 62264-3 Modified). International Society of Automation (ISA), 2013. 94 p.

5. Vasilev P. ANSI/ISA-95 Final capacity scheduling for software industry // IFAC-Papers Online. 2015. Vol. 48, Issue 24. P. 237-240. doi: http://doi.org/10.1016/j.ifacol.2015.12.089

6. Govindaraju R., Putra K. A methodology for Manufacturing Execution Systems (MES) implementation // IOP Conference Series: Materials Science and Engineering. 2016. Vol. 114. P. 012094. doi: http://doi.org/10.1088/1757-899x/114/1/012094

7. Fuchs F., Thiel K. Manufacturing Execution Systems. Optimal Design, Planning, and Deployment: monograph. New York: McGraw-Hill, 2009. 248 p.

8. Supervisory Control and Data Acquisition (SCADA) Systems National Communications System (NCS). Technical Information Bulettin 04-1. 2004. URL: https://www.cedengineering.com/ userfiles/SCADA \%20Systems.pdf

9. Liptak B. G., Halit E. Batch-Process Automation // Instrument Engineers' Handbook. Vol. 3. CRC Press, 2016. P. 232-259.

10. Emerson Process Management. URL: http://www3.emersonprocess.com/Systems/

11. OSI Soft. Pi system. URL: https://www.osisoft.com/pi-system/

12. Paszko C., Turner E. Laboratory information management systems: monograph. Boca Raton: CRC press, 2001. 242 p. doi: http://doi.org/10.1201/9780203908419

13. Hompel M., Thorsten S. Warehouse management: Automation and organization of warehouse and order picking systems: monograph. Berlin: Springer, 2006. 356 p. 
14. Jones K., Collis S. Computerized maintenance management systems // Property Management. 1996. Vol. 14, Issue 4. P. 33-37. doi: http://doi.org/10.1108/02637479610150757

15. PSI Gas Management Suite. URL: https://www.psigasandoil.com/ en/gas-management/gas-management-suite/

16. SIMONE Research Group. Solutions For Simulation And Optimisation In The Gas Industry. URL: http://www.simone.eu/ simone-simonesoftware.asp

17. Stark J. Product lifecycle management // Product Lifecycle Management. Vol. 1. Decision Engineering. Cham: Springer, 2015. 356 p. doi: http://doi.org/10.1007/978-3-319-17440-2

18. Customer relationship management: monograph / Knox S. et. al London: Routledge, 2007. 302 p. doi: http://doi.org/10.4324/ 9780080490854

19. SAP for Oil \& Gas. URL: https://www.sap.com/industries/ oil-gas.html

20. Totally Integrated Automation Portal. URL: https://www siemens.com/global/en/home/products/automation/industrysoftware/automation-software/tia-portal.html

21. Chekurin V. F., Prytula M. H., Khymko O. M. Metodolohiia MES i kompiuteryzatsiia upravlinnia HTS // Visnyk Natsionalnoho universytetu «Lvivska politekhnika». Kompiuterni systemy ta merezhi. 2014. Issue 806. P. 275-283.

22. Avtomatyzatsiia upravlinnia HTS: stan ta perspektyvy rozvytku z vykorystanniam MES / Ponomarov Yu. et. al. // Naftohazova haluz Ukrainy. 2015. Issue 5. P. 40-45.

23. Williams T. J. The Purdue enterprise reference architecture // Computers in Industry. 1994. Vol. 24, Issue 2-3. P. 141-158. doi: http://doi.org/10.1016/0166-3615(94)90017-5
24. MESA International. MESA Model. URL: http://www.mesa. org/en/modelstrategicinitiatives/MESAModel.asp

25. Hammer M., Champy J. Reengineering of Corporation. A manifesto for business revolution. New York: Harper Business Essentials, 2003. 257 p.

Chekurin Vasyl, Doctor of Physics and Mathematics, Professor Head of the Department of Mathematical Problems of Mechanics of Heterogeneous Solids, Ya. S. Pidstryhach Institute for Applied Problems of Mechanics and Mathematics of NAS of Ukraine, Lviv, Ukraine, e-mail: v.chekurin@gmail.com, ORCID: http://orcid.org/ 0000-0003-4973-3670

Ponomaryov Yuriy, PhD, Associate Professor, Deputy Director for Science, Research and Design Institute of Gas Transportation of JSC «Ukrtransgaz», Kharkiv, Ukraine, e-mail: ponomarev-yv@utg.ua, ORCID: http://orcid.org/0000-0002-5677-3657

Prytula Myroslav, PhD, Department of Designing Systems of Optimal Scheduling and Forecasting Operating Modes of GTS, Research and Design Institute of Gas Transportation of JSC «Ukrtransgaz», Kharkiv, Ukraine, e-mail: myroslav.prytula@gmail.com, ORCID: http://orcid.org/ 0000-0001-9259-4114

Khymko Olga, PhD, Associate Professor, Department of Automation and Computer-Integrated Technologies, Lviv Polytechnic National University,Ukraine, e-mail: olgakhymko@ukr.net, ORCID: http:// orcid.org/0000-0003-2641-8133 